Newfoundland and Labrador Studies

\title{
Shannon Webb-Campbell. Still No Word
}

\section{Morgon Mills}

Volume 33, numéro 2, 2018

URI : https://id.erudit.org/iderudit/1058084ar

DOI : https://doi.org/10.7202/1058084ar

Aller au sommaire du numéro

Éditeur(s)

Faculty of Arts, Memorial University

ISSN

1719-1726 (imprimé)

1715-1430 (numérique)

Découvrir la revue

Citer ce compte rendu

Mills, M. (2018). Compte rendu de [Shannon Webb-Campbell. Still No Word]. Newfoundland and Labrador Studies, 33(2). https://doi.org/10.7202/1058084ar d'utilisation que vous pouvez consulter en ligne.

https://apropos.erudit.org/fr/usagers/politique-dutilisation/ 
Shannon Webb-Campbell. Still No Word. St. John's: Breakwater Books, 2015. ISBN 978-1-55081-588-7

Shannon Webb-Campbell's Still No Word contemplates self and other, identity and ancestors, seeking and solitude and the sea. The mood is set in the first poem's opening line, "When you arrive at this loneliness" (15). From that starting point the reader moves through liminal spaces, sometimes explicitly directed by the text, other times free to peruse galleries of loosely interrelated images. The poems shift back and forth between sharp detail and disorienting unknowns, so that throughout the collection Webb-Campbell requires us constantly to look closely at what we are being shown and to think hard about the eyes through which we see it. The poems' complex treatment of identity is entangled with the twin processes of wounding and healing, and Webb-Campbell's final words, "woman, you are mighty" (70), give some idea of the outcome. At the same time, Webb-Campbell offers her readers far more than a therapeutic text, and even while celebrating strength she avoids reductive reconciliations.

Towards the begininng of Still No Word there is a helpfully direct statement of Webb-Campbell's poetics, in the form of a poem entitled "Towards Definition" and punctuated as prose (21). “Towards Definition" adheres to the grand tradition of "poetry is $x$ " assertions, and all 12 of its sentences begin with "Poetry is," though they break variously across 16 lines, giving us a single subject juxtaposed with 30 complements. Many of these are conventional provocations, but WebbCampbell pairs them with keywords of her own to establish a unique figurative vocabulary for the collection, one deeply indebted to the sea. For example, "Poetry is belly up to the bar, is ocean, inversion, weather, is masturbation, guesswork, high tide." On the other hand, the very next sentence begins, "Poetry is low tide," and a tongue-in-cheek self-awareness is repeatedly underscored throughout the poem, most obviously in the third short sentence of the first line: "Poetry is what it isn't." Elsewhere the poem can be quite clever, as in the lines, "is Perseids / and undergrowth," but the whole is mainly elevated from a 
compositional game by the turn in the final strophe, which offers a second grammatical subject and presents the culmination, if perhaps not quite a synthesis, of Webb-Campbell's definition of her medium:

\author{
Poetry is cartography: \\ mapmakers and sailors \\ trust it's \\ written in the stars.
}

The poem's right-hand alignment emphasizes the progressive, onward motion of the definition process, but this conclusion does seem final, and its relatively extended metaphor revises the playful offerings that precede it. In the end it seems that poetry is not in fact "ocean" after all, but a means or process of understanding and navigation, a way of getting answers.

For Webb-Campbell the natural home of poetry is in the sky, a site less fathomable than the sea, and more closely associated with fatal preordination than with physical inevitability. Not for nothing are stars the central element of the book's cover design, wherein the title is a constellation superimposed on the Milky Way. But if poetry inhabits the sky, the poet herself does not, and her cultural tradition is Atlantic and littoral. The ocean plays so central a role in Webb-Campbell's poetry that she includes the Atlantic in her acknowledgements: the sky provides the poetry, but the sea provides a good part of the subject matter. The book itself is like a shell held to the ear, housing a permanent echo of the waves. Its diction and theme bring us back constantly to the shore, an in-between space neither on the land nor at sea, where the reader is not quite either grounded or lost, not voyaging, but not altogether still, always exposed to motion. From this space the poetry can either look inward from the margin of the self or outward at the wide beyond, as in Keats's famous line, "on the shore / Of the wide world I stand alone."

As a unifying theme for the collection, solitude is nearly as omnipresent as the sea. It arises everywhere, even in a discussion of marriage, superficially the very least solitary of moments - "love is truce, 
/ a pact to honour and protect / one another's solitudes"(54) — and in the title of the collection itself. "Still no word" is one of the book's best lines, and one of its most important, because it is one of a few key moments pushing the text away from the celebration of redemptive self-discovery and towards a realization of the impossibility of full reconciliation with one's own identity.

The line appears in the shortest poem of the book, "A Healer's Lune," which directly addresses the poet's relationship not only to her Indigenous ancestors but, in the wider context of the collection, to herself (38):

Seek wounded healer,

cry out to unseen ancestors:

still no word.

A "lune" is an unconstrained haiku, more or less, and as in all short forms, its turn tells all. Here the ancestors' voice is a crushing silence, one that the poet has endured for some time. Given the presence of Webb-Campbell's grandmother and great-great-grandmother throughout the text, one might expect the opposite declaration, claiming ancestral inspiration and cultural continuity. After all, the collection's dedication reads, "we'll always be thick as thieves." Moreover, there is a well-established place in Canadian Indigenous literature for celebrations of ancestors' ongoing rhetorical lives. As Lee Maracle puts it, "When we sing, the bones of our ancestors hear our songs and they work their way to the surface of the land, singing themselves up" (305). Alternatively, Webb-Campbell's poetry itself could serve as the proof of her inheritance. The deceased are always literally silent and "unseen," but their descendants can figuratively stand in for them, and often do in other works. Webb-Campbell's words could be her ancestors' words, respoken, or at least her poetry could make that claim. Instead, she directly refutes this notion in "Tell Me, Medicine Woman, Who Do I Belong To?": 
I try to sing to you

in Gaelic, English,

French and Mi'kmaw

but don't know your languages (69).

Webb-Campbell has another idea in another mode, more confessional and, in this context, more courageous. Her emphasis upon the poet's estrangement from her ancestors places her in the tradition of Métis poets like Marilyn Dumont and Gregory Scofield, who seek a healed identity while insisting upon the enduring nature of its wounds. Far from problematizing an Indigenous poetics based on healing, relationality, and the natural world, this tradition enriches those themes by making room for complex personal and political histories that undermine identity itself. Focusing on the yearning for relationship, rather than on the ancestral continuity emphasized in poetry by Dan George, or in Jeannette Armstrong's “Indian Woman," for example, is a different way of honouring the same value of carrying on the spirit and tradition of those who have gone before. Without necessarily alluding to the intergenerational traumas inflicted by colonialism or to the ongoing reclamation of Indigenous identity in Newfoundland, Webb-Campbell allows space for these processes to inform the interpretation of her text - and at the same time, at the base of the poem lies the universal human experience of disappointment in discovering that life provides no answers.

In a 2015 interview with Lindsay Shane for No More Potlucks, Webb-Campbell says that "all healers are wounded healers," and she seems to confirm the association of the healer in "A Healer's Lune" with her great-grandmother, Mary Webb. Depending on how one parses the line, the wounded healer is not only being sought herself, but also seeking. If so, then it follows that each generation seeks healing from those who went before, but also that each generation is unable to be fully healed.

Few poetry collections are narrowly "about" anything, of course, and Still No Word is no exception. A good part of its appeal is the play with pronouns. In particular, Webb-Campbell handles the second 
person deftly and deviously, so that the "you" is sometimes the reader, sometimes someone else, and sometimes anyone at all, or even seemingly the poet herself. Sometimes, too, the "you" is an ambiguous overlay of perspectives, allowing for a rich, multi-layered understanding of the text, and the occasional discordances are sources of humour and dramatic irony. However, despite its play with pronouns and identity, and its frequent presentation of solitude and uncertainty, Still No Word is most satisfying in its individual portraits of actual people. Among these characters are a "Cod-Jigger," a "Fog Seeker," an "Octogenarian," and many others identified in individual poems only as "you," but given highly particularized treatments indicating that they are to be read variously as family members, lovers, or friends. Throughout these sketches, Webb-Campbell shows a keen eye for sensory detail and emotional nuance, and she creates moments and personalities that support the reader's empathy and human interest, and reward close reading. From these people, at least, some word has clearly come to the poet; and poems like "Chromosome Story" and "Our Tribe" give the lie to the idea of ancestral silence as well. Ultimately the collection itself is a powerful repudiation of its own central claim that no word is forthcoming from family or the past - but it is all the stronger for forwarding that claim and showcasing Webb-Campbell's own ambivalence. All healers are wounded, and poetry is what it isn't.

\section{Works Cited}

Maracle, Lee. "Indigenous Poetry and the Oral.” In Neal McLeod, ed., Indigenous Poetics in Canada, 305-10. Waterloo, Ont.: Wilfrid Laurier Press, 2014.

Webb-Campbell, Shannon. Interview by Lindsay Shane. No More Potlucks, July/Aug. 2015, at: nomorepotlucks.org/site/still-no-word-an-interviewwith-shannon-webb-campbell-lindsay-shane. Accessed 30 Sept. 2017.

Morgon Mills

Memorial University of Newfoundland 